\title{
More environmental spread
}

\section{Peter Brookes}

Mutation Research Letters. Editor S.H. Sobels. $12 / \mathrm{yr}$ in 3 vols. (Elsevier Biomedical.) Dfl.638, \$255. Teratogenesis, Carcinogenesis, and Mutagenesis. Editor Marvin S. Legator. 6/yr. (Alan R. Liss.) $\$ 95$ US, \$111.50 Europe.

BOTH of these journals (MRL and TCM, respectively) owe their existence to the current concern that environmental chemicals may be responsible for some human cancers and certain heritable genetic disorders. Professor Hermann Druckrey foresaw this possibility when he suggested in 1972 that the word "'genotoxic" should be used to describe the toxic, lethal and heritable effects on karyotic and extrakaryotic genetic material which may arise from chemical-DNA interactions.

The two journals overlap considerably in their fields of interest and are equally well produced; in particular the glossy paper allows excellent reproduction of blackand-white photographs. Also, despite clearly stated editorial policy on the subject, the journals share a lack of consistency in their presentation of references which some readers might find irritating and suggestive of weakness in the editorial office. These similarities apart, the two offer the potential author and reader quite different forms of scientific publication.

MRL is the fifth and latest addition to the sub-sections of the journal Mutation Research, joining the existing Regular, Environmental Mutagenesis, Reviews in Genetic Toxicology and General Toxicology Testing sections. The 1982 schedule envisages the publication of three volumes (a total of 11 issues) of MRL, in addition to the 12 volumes ( 32 issues) of the other sections of Mutation Research - the cost of the complete journal is now approaching a stiff $\$ 1,000$. In addition, I wonder if I am alone in my concern over the practice of publishers in designating a single issue of a journal as, for example, Vol. 104/4-5 so that the final issue of each volume can be given the number 6 . Does this really persuade librarians that they are getting value for money?

MRL publishes material in all the areas covered by its sister-sections of Mutation Research but restricts its authors to a maximum of six printed pages. The initial aim was to publish full papers (certainly not brief communications as the title might imply) within three months of submission and it was hoped to inform authors within two weeks of the acceptance or rejection of their paper. This schedule would seem to require an editorial decision or very cooperative referees and appears to have been a little optimistic; based on the acceptance dates on papers in recent issues it is proving difficult to achieve publication in less than 4-6 months. However, the format seems to be popular as judged by the increasing number of papers published each year.

The prime objective of TCM "is to foster interactions between investigators in the fields of teratogenesis, carcinogenesis and mutagenesis". The journal publishes full-length papers covering this wide area of research. No submission or acceptance date is given for the contributions.

TCM acknowledges support from the March of Dimes Birth Defects Foundation and this organization's annual conference seems to have yielded a number of papers for the journal, although this is not actually stated. The first volume of four issues appeared in 1980 while the second volume, originally scheduled for 1981 , was not in fact published until 1982 .

Titles of contributions in the area of carcinogenesis and mutagenesis suggest that they might equally well have been submitted to any one of many established journals. Authors of papers on teratogenesis would have a more limited choice, however, and the future of TCM may depend on its ability to attract papers in this latter area. If it can do this, and fulfil the hope of its editor and encourage collaboration between workers in its three fields of interest, it could serve a very useful purpose.

Peter Brookes is Chairman of the Chemical Carcinogenesis Section at the Pollards Wood Laboratory of the Institute of Cancer Research, Chalfont St Giles, Buckinghamshire.

\section{Red 'flu - and other viruses}

\section{D.H. Watson}

Soviet Progress in Virology. Editor V.M. Zhandov. 6/yr. (Allerton.) \$250 US, \$280 elsewhere.

JUST over a half century after the pioneering observations of Iwanowski on tobacco mosaic, the Institute of Virology bearing his name was founded in Moscow. This led later to the appearance of the journal Voprosy Virusologii (Problems of Virology) in 1956. The twenty-fifth anniversary of this publication was marked by the appearance of a special number late in 1980 and this issue was selected to be the first in a regular series of cover to cover

\section{Butterworth} Scientific Limited Journals Division

at Guildford are pleased

to announce that they will

be publishing:

The Round Table:

The Commonwealth Journal of International Affairs on behalf of the Round Table Limited from the January 1983 issue.

International Affairs:

The quarterly journal of the Royal Institute of International Affairs from the January 1983 issue.

International Studies Quarterly: The quarterly journal of the

International Studies

Association in the U.S.A. from the March 1983 issue.

\section{Political Studies:}

On behalf of the Political Studies Association of the United Kingdom from the March 1983 issue.

For further information and subscription details. please contact:

Jan Holloway,

Sales Promotion Executive

Butterworth Scientific

Limited - Journals Division

P.O. Box 63, Westbury House, Bury Street, Guildford,

Surrey GU12. 5BH.

Telephone: 0483.31261

Telex: 859556 SCITEC G 